\title{
Review
}

\section{The role of mitochondrial factors in apoptosis: a Russian roulette with more than one bullet}

\author{
G van Loo ${ }^{1}$, X Saelens ${ }^{1}$, M van Gurp ${ }^{1}$ M MacFarlane ${ }^{2}$, \\ SJ Martin ${ }^{3}$ and $P$ Vandenabeele ${ }^{\star, 1}$ \\ ${ }^{1}$ Molecular Signalling and Cell Death Unit, Department of Molecular Biomedical \\ Research, VIB, Gent University, K.L. Ledeganckstraat 35, B-9000 Ghent, \\ Belgium \\ ${ }^{2}$ Medical Research Council Toxicology Unit, Hodgkin Building, University of \\ Leicester, Leicester, UK \\ 3 Molecular Cell Biology Laboratory, Department of Genetics, The Smurfit \\ Institute, Trinity College, Dublin, Ireland \\ * Corresponding author: P Vandenabeele, K.L. Ledeganckstraat 35, B-9000 \\ Ghent, Belgium. Tel: 32-9-264-51-31; Fax: 32-9-264-53-48; \\ E-mail: peter.vandenabeele@dmb.rug.ac.be
}

Received 14.4.02; revised 7.6.02; accepted 11.6.02

Edited by E Alnemri

\begin{abstract}
Mitochondria are 'life-essential' organelles for the production of metabolic energy in the form of ATP. Paradoxically mitochondria also play a key role in controlling the pathways that lead to cell death. This latter role of mitochondria is more than just a 'loss of function' resulting in an energy deficit but is an active process involving different mitochondrial proteins. Cytochrome $c$ was the first characterised mitochondrial factor shown to be released from the mitochondrial intermembrane space and to be actively implicated in apoptotic cell death. Since then, other mitochondrial proteins, such as AIF, Smac/DIABLO, endonuclease $G$ and Omi/HtrA2, were found to undergo release during apoptosis and have been implicated in various aspects of the cell death process. Members of the Bcl-2 protein family control the integrity and response of mitochondria to apoptotic signals. The molecular mechanism by which mitochondrial intermembrane space proteins are released and the regulation of mitochondrial homeostasis by $\mathrm{Bcl}-2$ proteins is still elusive. This review summarises and evaluates the current knowledge concerning the complex role of released mitochondrial proteins in the apoptotic process.

Cell Death and Differentiation (2002) 9, 1031-1042. doi:10.1038/sj.cdd. 4401088
\end{abstract}

Keywords: apoptosis; mitochondria; apoptosome; caspase

Abbreviations: AIF, apoptosis-inducing factor; Apaf-1, apoptotic protease-activating factor 1; BIR, baculoviral IAP repeat; DIABLO, direct IAP-binding protein with low pl; DISC, death-inducing signalling complex; ES, embryonic stem; HtrA, high temperature requirement $A$; PTP, permeability transition pore; Smac, second mitochondria-derived activator of caspases; tBid, truncated Bid; XIAP, X-linked inhibitor-of-apoptosis protein

\section{Introduction}

Since the pioneering work of Xiaodong Wang, ${ }^{1}$ increasing evidence has been provided that mitochondrial constituents are actively involved in the regulation of apoptotic cell death. Originally, the contribution of mitochondria to apoptosis was described in terms of disruption of the mitochondrial transmembrane potential $(\Delta \psi \mathrm{m})$, which results from an asymmetric distribution of protons on both sides of the inner mitochondrial membrane. ${ }^{2}$ This $\Delta \psi \mathrm{m}$ creates an electrochemical gradient essential for ATP synthetase activity in the oxidative phosphorylation pathway. $\Delta \psi \mathrm{m}$ collapse was considered as the 'point-of-no-return' of the death program. ${ }^{3}$ A breakthrough in the recognition of the central role of mitochondria in apoptosis came with the finding that cytochrome $c$, an electron shuttle molecule in the oxidative phosphorylation pathway, is involved in caspase activation after its release from mitochondria. ${ }^{4}$ At least in certain experimental settings, release of cytochrome $c$ from the mitochondria can occur prior to $\Delta \psi \mathrm{m}$ collapse. ${ }^{5-7}$ In Fasmediated apoptosis in mouse hepatocytes, mitochondrial respiration is gradually impaired over time, concomitant with the release of cytochrome $c$. Whereas in an early stage of apoptosis, respiratory dysfunctions can still be overcome by adding exogenous cytochrome $c$, at a later stage, when there is $\Delta \psi \mathrm{m}$ loss, exogenous cytochrome $c$ can no longer rescue mitochondrial respiratory function. ${ }^{8}$ Considering that apoptosis is an energy consuming process, ${ }^{9}$ it is plausible that the fraction of cytochrome $c$ released early in the process will participate in apoptosome formation, whereas the cytochrome $c$ portion that remains mitochondria associated will temporally warrant sustained ATP production. The initially released pool of cytochrome $c$ might be the soluble fraction from the intermembrane space whereas the second pool might comprise the fraction more tightly associated with the inner mitochondrial membrane. ${ }^{10,11}$ Over time, progressive damage to mitochondria becomes irreversible, ensuring cell death. The 'point-of-no-return' is thus not an abrupt phenomenon but rather a process accumulating in the decisive disruption of the mitochondrial membrane potential.

Like cytochrome $c$, several other mitochondrial intermembrane proteins that are released into the cytosol after exposure to apoptotic stimuli have since been identified. ${ }^{12-21}$ The exact role of these proteins in the process of cell death is still unclear and in most cases has only been reported in qualitative terms. Recent data demonstrate that an early relocalisation of these mitochondrial proteins results in the direct activation of caspases, the 


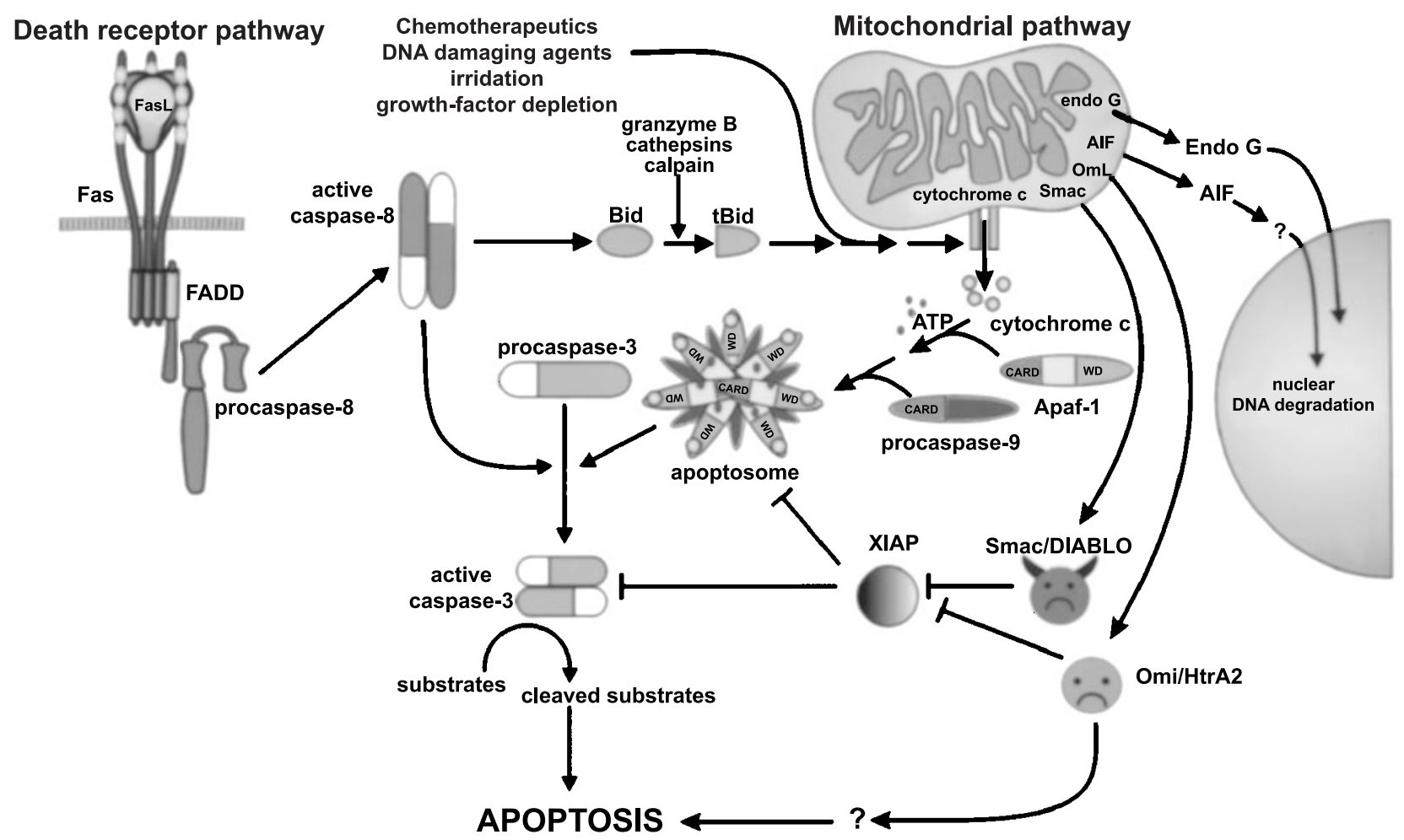

Figure 1 Many death signals converge onto mitochondria and release multiple intermembrane space proteins. A variety of apoptotic stimuli (death domain receptors, chemotherapeutics, DNA-damaging agents, growth-factor withdrawal, irradiation) trigger mitochondria, which results in the release of apoptotic proteins including cytochrome $c$, AIF, endonuclease G, Smac/DIABLO and Omi/HtrA2. Cytochrome $c$ induces caspase activation by binding to Apaf-1. Smac/DIABLO and $\mathrm{Omi} / \mathrm{HtrA} 2$ can neutralise IAP inhibition of caspases. AIF and endonuclease $\mathrm{G}$ are involved in caspase-independent nuclear DNA degradation

neutralisation of cytosolic caspase inhibitors and the activation of nucleases. . $^{12-21}$ This review summarises recent findings and focuses on the current evidence for a quantitative contribution of these mitochondrial factors to apoptosis.

\section{Induction of mitochondrial dysfunction}

Numerous cell damage pathways converge on mitochondria and induce permeabilisation of mitochondrial membranes and release of mitochondrial proteins. ${ }^{22}$ These include cytotoxic drugs, DNA-damaging agents, heat-shock, hypoxia, growthfactor withdrawal, irradiation and death domain receptor signalling (Figure 1). Various stress stimuli stabilise the tumour suppressor protein p53, which promotes cell-cycle arrest thereby enabling DNA repair or apoptosis. The exact mechanism of apoptosis induction is still unknown but would be predicted to involve activation of the mitochondrial pathway and subsequent activation of downstream caspases. ${ }^{23}$ Several chemotherapeutic agents and anticancer drugs also act on mitochondria, although their exact mechanism of action is unclear. ${ }^{23,24}$ The mitochondrial and death receptor pathways are intimately connected. The main molecular link connecting the death-inducing signalling complex (DISC) ${ }^{25}$ and mitochondria is the caspase-8-mediated cleavage of Bid, a $\mathrm{BH} 3$ only member of the $\mathrm{Bcl}-2$ protein family, to generate a $15 \mathrm{kDa}$ fragment. Consequently, truncated Bid (tBid) trans- locates to the mitochondria where it induces the release of cytochrome $c .^{26,27}$ The mechanisms by which tBid rapidly and selectively targets the mitochondria are not known. Recent studies show that post-translational $\mathrm{N}$-myristoylation of tBid following cleavage by caspase-8, serves as an activating switch for targeting tBid to mitochondria. ${ }^{28}$ Others provide evidence that cardiolipin mediates the mitochondrial targeting of tBid by binding to a specific domain in tBid. ${ }^{29}$ Cardiolipin is found at high concentrations throughout the inner mitochondrial membrane, including the contact sites between the inner and outer membrane. Immunogold tomography revealed that these contact sites are the preferential targets for association of $\mathrm{tBid} .^{30}$ The presence of $\mathrm{Bcl}-2$ or $\mathrm{Bcl}-\mathrm{x}_{\mathrm{L}}$ still allows cleavage and translocation of tBid, but prevents the release of cytochrome $c$. $^{31}$

Additional pathways for Bid activation have been proposed. Granzyme B, a cytotoxic T-cell specific serine protease, was shown to cleave Bid, activating the mitochondrial pathway. ${ }^{32-34}$ On the other hand, granzyme $B$ also affects mitochondria in a Bid-independent way resulting in mitochondrial depolarisation and cell death, even though these mitochondria fail to release cytochrome $c^{35,36}$ Also lysosomal proteases and the calcium-dependent cysteine protease calpain were shown to cleave Bid in the protease-sensitive region preceding the $\mathrm{BH} 3$ domain, suggesting a role for Bid as a sensor for the integrity of lysosomes and the endoplasmic reticulum. ${ }^{37,38}$ 
Despite the overwhelming evidence for a central role for tBid, the phenotype of Bid-deficient mice is limited with respect to apoptosis induction. Bid-deficient mice are resistant to Fas- and TNF-induced hepatocyte apoptosis ${ }^{39}$ but cells from these mice are still susceptible to granzyme B-induced death ${ }^{36}$ and to drug and stress-induced apoptosis. ${ }^{39}$ Furthermore, Bid-deficient mice develop normally, in sharp contrast to the embryonic lethality caused by cytochrome $c$, caspase- 9 or Apaf-1 deficiency, ${ }^{40}$ suggesting that tBid generation is not required for programmed cell death in development and may be compensated for by downstream factors such as Bax and Bak. $^{41}$

\section{Regulation of the mitochondrial response by Bcl-2 family proteins}

Mitochondria are the primary site of action of the $\mathrm{Bcl}-2$ protein family. Both pro-apoptotic (Bid, Bax, Bak, Bok, Bik, Bnip3, Bad, Bim, Bmf, Noxa, Puma) and anti-apoptotic members (Bcl-2, Bcl- $\mathrm{x}_{\mathrm{L}}, \mathrm{Bcl}-\mathrm{w}, \mathrm{Mcl}-1, \mathrm{Boo}, \mathrm{Bcl}-\mathrm{B}$ ) are characterised by the presence of $\mathrm{Bcl}-2$ homology $(\mathrm{BH})$ domains. ${ }^{42-44}$ Members of the Bid-subfamily (Bid, Bad, Bik, Bim, Bmf, Bnip3, Noxa, Puma) only share the $\mathrm{BH} 3$ domain and are otherwise unrelated. ${ }^{43}$ Members of the functionally opposing subfamilies can heterodimerise through interaction between the amphipathic $\mathrm{BH} 3 \alpha$-helix of the pro-apoptotic proteins and the hydrophobic groove on the anti-apoptotic members, created by the $\alpha$ helices in the $\mathrm{BH} 1, \mathrm{BH} 2$ and $\mathrm{BH} 3$ regions. ${ }^{43}$
A BH3-only protein can thus serve as a ligand that binds an anti-apoptotic $\mathrm{Bcl}-2$ protein. Bax-like proteins (Bax, Bak and Bok) can also heterodimerise with anti-apoptotic $\mathrm{Bcl}-2$ proteins via the $\mathrm{BH} 3$ domain. ${ }^{42}$

The precise molecular mechanism by which $\mathrm{Bcl}-2$ family proteins protect from or induce mitochondrial damage is still controversial. Different models have been proposed to explain the permeabilisation of the mitochondrial membrane and the release of mitochondrial proteins (Figure 2). ${ }^{45}$ The oldest model (Figure 2A) argues that cytochrome $c$ is released as a result of the opening of the permeability transition pore (PTP), a large, poorly characterised protein complex at contact sites between the outer and inner mitochondrial membranes. ${ }^{46}$ The core components of these contact sites are the ANT protein (adenine nucleotide translocator), found in the inner membrane, and the VDAC protein (voltage-dependent anion channel), located in the outer membrane. The outer membrane is normally permeable for solutes up to $5 \mathrm{kDa}$, allowing the exchange of respiratory-chain substrates (ADP/ATP, NADH, FADH) between the intermembrane space and the cytosol. The inner membrane, however, is almost impermeable, a feature essential for maintaining an electrochemical potential across the inner membrane required for oxidative phosphorylation. ${ }^{46}$ Opening of the PTP is postulated to result in the loss of mitochondrial membrane potential, swelling of the mitochondrial matrix and rupture of the outer membrane, allowing the release of proteins from the intermembrane space. An alternative model suggests that

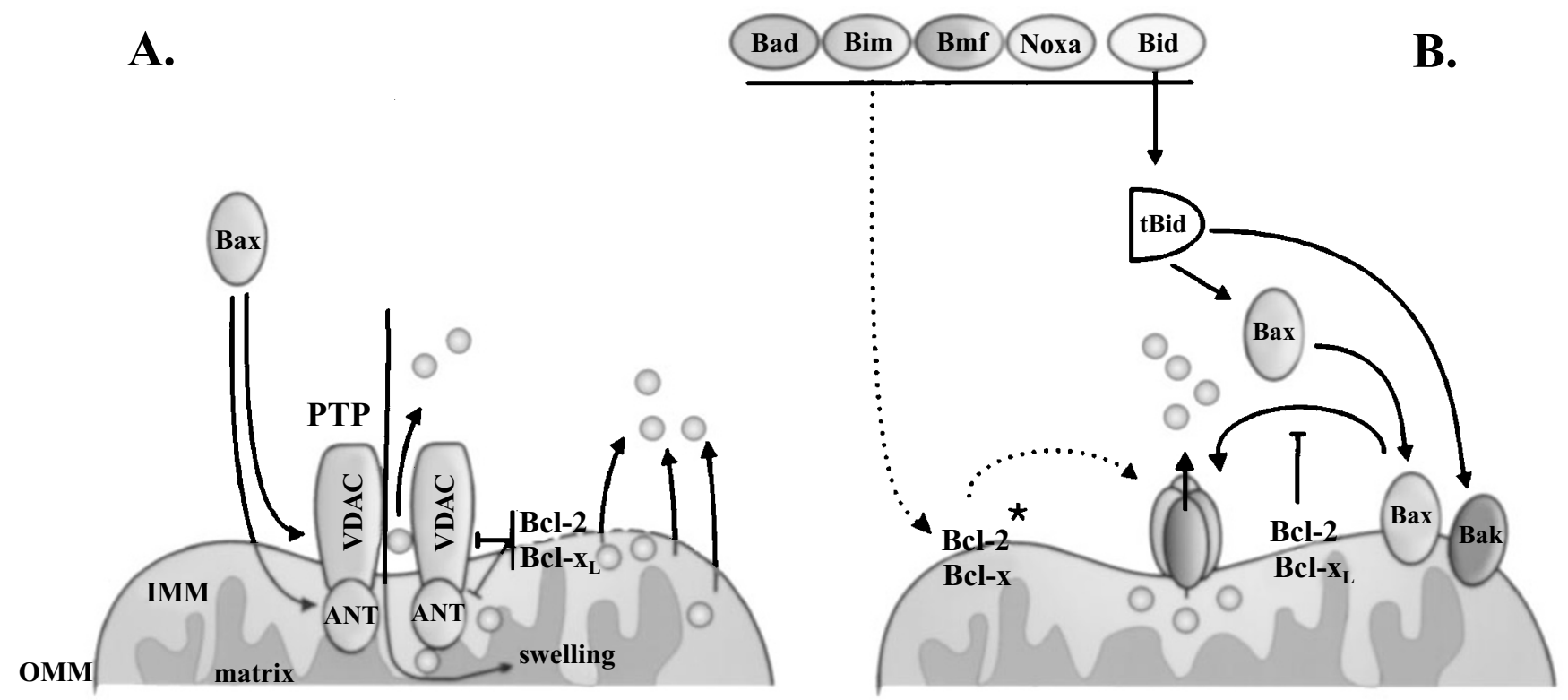

Figure 2 Regulation of mitochondrial protein release. (A) PTP model. The permeability transition pore (PTP) complex consists of several transmembrane proteins with core components VDAC in the outer mitochondrial membrane (OMM) and ANT in the inner mitochondrial membrane (IMM). Pro-apoptotic Bcl-2 proteins, such as Bax, bind to the PTP complex and induce its opening resulting in the release of intermembrane space proteins such as cytochrome $c$. In another model PTP opening results in rupture of the OMM due to swelling of the mitochondrial matrix and consecutive release of intermembrane space proteins. Anti-apoptotic Bcl-2 proteins, such as Bcl-2 and Bcl- $x_{\mathrm{L}}$, prevent the opening of the PTP. ${ }^{45,46}$ (B) Bax/Bak model. BH3-only proteins, such as tBid, interact with cytosolic Bax inducing its translocation to and oligomerisation in the OMM. tBid can also translocate to mitochondria activating Bak and inducing Bak oligomerisation in the OMM. Bax and Bak form heterotetrameric channels through which mitochondrial proteins are released. Anti-apoptotic Bcl-2 proteins, such as $\mathrm{Bcl}-2$ and $\mathrm{Bcl}-\mathrm{x}_{\mathrm{L}}$, inhibit the conformational change and oligomerization of Bax and Bak. ${ }^{45}$ The pro-apoptotic BH3-only proteins Bad, Bim, Bmf and Noxa bind to anti-apoptotic Bcl-2 members changing the conformation of the latter and so 'switching' them from anti-apoptotic to pro-apoptotic factors $\left(\mathrm{Bcl}-2^{*}, \mathrm{Bcl}^{\left.-\mathrm{x}_{\mathrm{L}}{ }^{*}\right)}\right.$ that require Bax/Bak for their activity ${ }^{44}$ 
intermembrane space proteins would be released through the PTP itself. Pro- and anti-apoptotic $\mathrm{Bcl}-2$ proteins were shown to interact with the PTP. ${ }^{45,46}$ This PTP-Bcl-2 family member interaction has been reported to be either through $\mathrm{ANT}^{47}$ or through VDAC. ${ }^{48} \mathrm{Bax}$ and Bak are believed to promote the opening of the PTP allowing cytochrome $c$ to pass through it, while anti-apoptotic $\mathrm{Bcl}-2$ and $\mathrm{Bcl}-\mathrm{x}_{\mathrm{L}}$ would favour the closure of the PTP. ${ }^{48}$ However, the exact mechanism whereby pro-apoptotic $\mathrm{Bcl}-2$ proteins could modulate the opening of the PTP is still not clear. Moreover, how PTP, which are located at contact sites between outer and inner mitochondrial membrane, allow the passage of intermembrane space proteins is not yet explained in molecular terms.

A second model (Figure $2 \mathrm{~B}$ ) proposes that at least some pro-apoptotic $\mathrm{Bcl}-2$ proteins are able to form tetrameric outermembrane channels that could mediate the release of apoptogenic factors from the mitochondrial intermembrane space. Genetic knockout studies place Bax and Bak downstream of tBid as Bax-Bak double knockout cells are completely resistant to mitochondrial cytochrome $c$ release during apoptosis. ${ }^{41}$ tBid possesses pore-forming activity allowing the release of cytochrome $c$ without a drop in the mitochondrial transmembrane potential. ${ }^{49,50}$ Bax and Bak are thought to undergo a conformational change after interaction with tBid. Bax is a monomeric soluble cytosolic factor in healthy cells but oligomerises, translocates and inserts into the mitochondrial outer membrane upon induction of apoptosis. ${ }^{51,52}$ In contrast to Bax, Bak resides in the outer membrane of mitochondria but also undergoes oligomerisation and activation upon apoptosis. ${ }^{5}$ Both proteins can form tetrameric channels through which cytochrome $c$ can escape. The BH3-only proteins Bad, Bim, Bmf and Noxa bind to anti-apoptotic Bcl-2 members but not to Bax and Bak. It was proposed that when these $\mathrm{BH} 3-$ only proteins become activated, they are released from an inactivating complex and bind to $\mathrm{Bcl}-2$ and its homologues changing their conformation. ${ }^{44}$ The antiapoptotic Bcl-2-like proteins with altered conformation would now resemble pro-apoptotic Bax/Bak-like factors and stimulate the aggregation of the latter in a homotypic 'prion'-like manner. ${ }^{44}$ In their anti-apoptotic conformation, $\mathrm{Bcl}-2$ and $\mathrm{Bcl}-\mathrm{x}_{\mathrm{L}}$ inhibit the conformational change and oligomerisation of Bax and Bak by sequestering $\mathrm{BH}$-only molecules in stable mitochondrial complexes preventing the activation of Bax and Bak (Figure 2B). ${ }^{53,54}$ Using electrophysiological methods, a comparable channel activity in the outer membrane of mitochondria was recently proposed by Pavlov et al:: their 'MAC' model (mitochondria apoptosisinduced channel) may represent a channel similar to the Bax/Bak channel but was shown to have a pore diameter significantly larger than that of the Bax/Bak channel allowing diffusion of proteins larger than cytochrome $c$ (12 kDa), such as AIF (57 kDa) and Smac/DIABLO (which behaves as a $\sim 100 \mathrm{kDa}$ dimer $\left.{ }^{55}\right) .{ }^{56}$ Although Bax plays an essential role in MAC activation, this channel most probably contains other additional outer membrane proteins.

Recently, a third model of Bid-mediated perturbation of mitochondrial function has emerged. Several reports argue for an interaction between Bid and phospholipid metabo- lism. Following cleavage by caspase-8, the C-terminus of Bid translocates from the cytosol to the mitochondrial contact sites, the structures that form the contacts between the outer and inner mitochondrial membranes. This relocation occurs in a cardiolipin-dependent way. ${ }^{29,30}$ Truncated Bid is far more potent in cardiolipin binding than Bid, explaining the requirement for proteolytic activation during apoptosis. ${ }^{29}$ Very recently another connection was made with phospholipid metabolism. Bid possesses phospholipid transfer activity reflecting its role in dynamic remodelling of intracellular membrane. ${ }^{57}$ Enhanced availability of phosphatidylglycerol, phosphatic acid and phosphatidylcholine, but not phosphatidylserine, induces relocation of Bid and tBid to the membranes. Other Bcl-2 family members such as $\mathrm{Bcl}-\mathrm{x}_{\mathrm{L}}$ and Bak do not possess this lipid transfer activity. How can this be associated with the proapoptotic function of Bid and tBid? Death domain receptor and other proapoptotic stimuli often result in the activation of phospholipases ${ }^{58}$ causing changes in phospholipid homeostasis, and resulting in enhanced lysolipids. These are preferentially transferred by tBid to the mitochondria and may contribute to the loss of membrane integrity. ${ }^{57,59}$

\section{Mitochondrial proteins released during SR>apoptotic cell death}

\section{Cytochrome $c$}

Cytochrome $c$ was the first apoptogenic intermembrane protein identified as being released from mitochondria during apoptosis. Using a cell free system, Xiaodong Wang and colleagues showed that cytochrome $c$ is required for the proteolytic activation of procaspase- $3 .{ }^{4}$ In addition, microinjection of cytochrome $c$ results in apoptosis. ${ }^{60}$ Following release from mitochondria, cytochrome $c$, together with the 'apoptotis protease-activator factor 1' (Apaf-1), dATP and cytosolic procaspase- 9 , forms a high molecular weight caspase-activating complex, termed the 'apoptosome' (Figure 1). ${ }^{61-64}$ Once assembled, the apoptosome processes and activates procaspase- 9 as the initiator caspase, which in turn proteolytically activates the executioner procaspase- 3 and procaspase-7. A proteolytic cascade is then initiated in which caspase- 3 activates procaspase-2, $-6,-8$ and -10 , resulting in a feedback amplification of the apoptotic signal. ${ }^{65,66}$ Caspase-3 can further amplify the proteolytic processing of caspase- 9 by generating an alternative proteolytic p10 caspase-9 fragment lacking the amino-terminal XIAP-interacting motif and thereby evading caspase inhibition. ${ }^{67}$ Recently, the three-dimensional structure of the apoptosome has been determined, revealing a wheel-shaped structure with sevenfold symmetry. ${ }^{68}$

A fundamental difference between the initial activation of procaspase- 9 and other procaspases is its requirement for Apaf-1 and dATP. Apaf-1 is a cytosolic protein that comprises an $\mathrm{N}$-terminal caspase-recruitment domain (CARD), a nucleotide-binding domain and a C-terminal domain containing multiple WD-40 repeats. ${ }^{62}$ The CARD domain of Apaf-1 acts as a docking region for the recruitment of procaspase- 9 but is normally not exposed 
unless Apaf- 1 is activated by dATP and cytochrome $c .^{61,69}$ Apaf-1 binds dATP poorly, but the affinity of both molecules is significantly increased upon binding of cytochrome $c .^{70}$ WD-40 repeats are found in a wide variety of proteins and represent a protein - protein interaction motif. ${ }^{71}$ The WD-40 motif of Apaf-1 was shown to be required for binding of cytochrome $c^{72-74}$ Mutational substitution analysis has provided indirect evidence that cytochrome $c$ is completely wrapped around Apaf-1 upon binding. ${ }^{75}$ This contrasts with the interaction of cytochrome $c$ with its partners in the electron transfer pathway, where only the lysine-rich interphase implicated in heme binding is involved. Yet the dual function of cytochrome $c$ in both oxidative phosphorylation and apoptosome formation can be uncoupled, as exemplified in Saccharomyces cerevisiae, where cytochrome $c$ is incapable of activating Apaf- 1 in a cell free system. $^{76,77}$

The importance of cytochrome $c$, Apaf-1 and caspase- 9 for the execution of apoptosis has been confirmed by genetic studies in mice through the targeted disruption of the corresponding genes, resulting in embryonic or perinatal death of the homozygous knockout-animals. ${ }^{78-82}$ Embryonic stem cells and fibroblasts derived from these null-mice demonstrate defects in response to a variety of apoptotic stimuli and no procaspase- 9 activation occurred in any of the knockout cells. The remarkable similarity between the phenotypes of the Apaf-1 and caspase-9 knockout mice has confirmed that these proteins act in the same pathway. Cytochrome $c$ deficient mice die in utero around midgestation. Despite their severe phenotype and developmental delay, cytochrome $c$ knockout embryos seem capable of developing differentiated tissues derived from the three germ layers, indicating that cytochrome $c$, unlike AIF, is not essential for cavitation. ${ }^{78,83}$

\section{Apoptosis Inducing Factor (AIF)}

The mammalian mitochondrial protein AIF was identified as a $57 \mathrm{kDa}$ flavoprotein sharing homology with bacterial, plant and fungal oxidoreductases. ${ }^{12}$ AIF, which bears both mitochondrial and nuclear signal sequences, is normally confined to the mitochondrial intermembrane space but translocates to the nucleus in response to apoptogenic stimuli causing large-scale $(\sim 50 \mathrm{~kb})$ DNA fragmentation and peripheral chromatin condensation, but not oligonucleosomal DNA laddering. ${ }^{12,84}$ Besides its nuclear effects, overexpression of AIF induces other characteristics of apoptotic cell death, such as the dissipation of the mitochondrial transmembrane potential and exposure of phosphatidylserine on the plasma membrane. ${ }^{12}$ The molecular mechanism whereby AIF exerts its cytotoxic activity remains unclear, since AIF does not contain intrinsic nuclease activity and the oxidoreductase activity is not required for its apoptogenic function. ${ }^{85}$ None of these AIF effects, however, are prevented by the wide-range caspase inhibitor zVAD-fmk. Recent data indicate that the heat-shock protein Hsp 70 can bind and antagonise AIF, ${ }^{86}$ explaining in part the cytoprotective property of Hsp70. Although AIF seems to mediate apoptotic functions in a caspase-independent way, it is unclear what its contribution is to the apoptotic process as AIF is released together with cytochrome $c$ and other proapoptotic mitochondrial factors. Moreover, embryonic stem cells from AIF deficient animals were shown to be sensitive to most conventional triggers of bona fide apoptosis, such as staurosporin, etoposide and UV irradiation. However, they are resistant to cell death after growth factor deprivation. ${ }^{83}$ Nevertheless, AIF-deficient mice exhibit a clear cell death associated phenotype as embryoid bodies from AIF $^{-1}$ ES cells lack the formation of the proamniotic cavity normally induced by death of the central core of ectodermal cells. ${ }^{83}$ This phenomenon is considered as the very first wave of programmed cell death indispensable for normal morphogenesis. ${ }^{87}$ Whether the observed phenotype is the result of the loss of the cytotoxic property of AIF or of its oxidoreductase function is unclear. AIF-dependent cell death can be genetically uncoupled from Apaf- 1 and caspase- 9 expression as was shown in Apaf- $1^{-1-}$ and caspase- $9^{-1-}$ ES cells, indicating that AIF acts independent to the cytochrome c/Apaf-1/caspase-9 apoptosome. ${ }^{83}$ The existence of AIF homologues in plants and fungi suggests that the role of AIF in cell death may represent a caspaseindependent ancestral pathway. ${ }^{88}$

\section{Smac/DIABLO}

The Apaf-1/cytochrome $c$ apoptosome complex was sown to contain the inhibitor of apoptosis protein XIAP, which binds and sequesters activated caspase- 3 produced within the apoptosome. ${ }^{89}$ In this context, Alnemri and colleagues also demonstrated interaction of XIAP with caspase-9 in the apoptosome complex. Procaspase- 9 is initially processed at Asp315 resulting in the generation of an aminoterminal recognition motif in the linker region on the small subunit, which binds to the BIR3 domain of XIAP. ${ }^{90}$ Processed caspase-3, however, interacts with the BIR2 domain of XIAP. These interactions with caspase- 9 and -3 allow XIAP to efficiently block activated caspases and thus prevent the proteolytic cascade. If the proapoptotic stimulus persists or is overwhelming, the progressive generation of activated caspases on the one hand, and the competition of mitochondrial proteins that block XIAP activity on the other, can overcome the protective effect of XIAP.

One of these mitochondrial XIAP antagonists is Smac/ DIABLO, a $29 \mathrm{kDa}$ mitochondrial protein, which is processed to a $23 \mathrm{kDa}$ mature protein and translocates to the cytosol after an apoptotic trigger. Besides its interaction with XIAP, Smac/DIABLO was shown to bind other IAP proteins including $\mathrm{C}-\mathrm{IAP} 1, \mathrm{C}-\mathrm{IAP} 2$, survivin and baculoviral Op-IAP. ${ }^{13,14}$ As for caspase-9, a similar recognition motif at the aminoterminus of mature Smac/DIABLO binds the BIR3 domain of XIAP. ${ }^{55,90-92}$ The same aminoterminal sequence of Smac/DIABLO also forms a stable complex with the BIR2-domain of XIAP allowing competition with the XIAP-dependent inhibition of caspase-3 and $-7 .^{55,93-95}$ Interestingly, the aminoterminal residues of Smac/DIABLO and caspase- 9 that interact with the BIR3 domain of XIAP share significant homology with the Drosophila proteins Hid, Grim and Reaper, ${ }^{90,96}$ three cytosolic proteins that promote apoptosis in the fly by antagonising DIAP-1 and $-2 .^{97-99}$ Very recently, another Drosophila cell death protein was described, termed Sickle, which binds IAPs 
through a similar motif and neutralises their anti-apoptotic activity. ${ }^{100-102}$ It is remarkable that proteins that have no further homology such as Sickle, Grim, Hid and Reaper in Drosophila and caspase-9, Smac/DIABLO and Omi/HtrA2 in mammals, share this aminoterminal IAP-binding motif. The same motif is utilised in completely different protein contexts: in the case of caspase- 9 as an anti-apoptotic mechanism to recruit IAPs, or in the case of Grim, Hid, Reaper, Sickle, Smac/DIABLO and Omi/HtrA2 as a proapoptotic mechanism to block IAPs, suggesting a stringent co-evolution of pro- and anti-apoptotic mechanisms. Smac/DIABLO also possesses another way of inducing apoptosis, independent of its IAP-binding domain. ${ }^{103}$ This is revealed by the proapoptotic activity of Smac $\beta$, a Smac/DIABLO splice variant, lacking the mitochondrial-targeting sequence and the ability to bind IAPs. Furthermore, overexpression of a truncated Smac/ DIABLO mutant, which lacks the entire IAP-interacting domain, potentiates apoptosis to the same extent as does Smac/DIABLO and Smac $\beta$, suggesting that this alternative proapoptotic mechanism of Smac/DIABLO may prevail. $^{103}$ The underlying mechanism of this IAPindependent activity is currently unknown. Whether Smac/DIABLO is an essential factor in the apoptotic process or just a disorientated mitochondrial protein is still unclear, although the presence of the IAP binding motif favours the first view. However, Smac/DIABLO-deficient mice are completely viable and do not show any abnormality. All types of Smac/DIABLO-deficient primary cells respond normally to a broad range of apoptotic stimuli. ${ }^{104}$ These observations suggest the existence of redundant factors compensating for the loss of Smac/ DIABLO, probably Omi/HtrA2, or that Smac/DIABLO has no essential and general role in apoptosis during development.

\section{Omi/HtrA2}

Another mitochondrial factor that shares functional properties with Smac/DIABLO is the serine protease Omi, ${ }^{105}$ also known as HtrA2. ${ }^{106}$ Upon apoptosis induction with anti-Fas, TRAIL, staurosporin and UV-irradiation, this protease is released from the intermembrane space of mitochondria and interacts with cytosolic IAP proteins via a similar IAP binding motif as described above. ${ }^{17-21} \mathrm{Omi} / \mathrm{HtrA} 2$ was identified as a $49 \mathrm{kDa}$ serine protease, homologous to the bacterial DegP/HtrA protein, and was suggested to be involved in cellular stress response pathways. ${ }^{105,106}$ Although originally defined as being localised to the endoplasmic reticulum ${ }^{105}$ or the nucleus, ${ }^{106}$ a mitochondrial localisation signal was identified using computational models and its presence in mitochondria was confirmed using Omi/HtrA2 specific antibodies. ${ }^{17-21}$ Upon mitochondrial transport, an aminoterminal presequence is cleaved off and Omi/HtrA2 is processed to the mature $37 \mathrm{kDa}$ protein which is released into the cytosol after an apoptotic trigger. ${ }^{17-21,107}$ Whether Omi/HtrA2 undergoes autocatalytic cleavage for correct processing or whether it is cleaved by another mitochondrial protease is unknown. The free aminoterminus of processed mature Omi/HtrA2 exposes the 'conserved' tetrapeptide motif essential for IAP interaction.
Omi/HtrA2 interacts with both the BIR2 and BIR3 domains of $\mathrm{XIAP}$, although with higher affinity for the BIR2, as opposed to Smac/DIABLO, which preferentially binds the BIR3 domain. ${ }^{17,20}$ This selectivity suggests that Omi/HtrA2 may promote preferentially caspase-3 activation rather than caspase- 9 activation through inhibition of XIAP.

Although Omi/HtrA2 and Smac/DIABLO both seem to target XIAP once released into the cytosol, their distribution pattern is quite different. Northern blot analysis of mRNA showed that Smac/DIABLO was most abundant in heart, liver, kidney and testis with no expression detected in skeletal muscle, lung, thymus and brain. ${ }^{13,14}$ In contrast Omi/HtrA2 mRNA, like XIAP, is expressed ubiquitously. ${ }^{105,106}$ This suggests that Smac/DIABLO and Omi/ $\mathrm{Htr}$ 2 may have a redundant function in certain cell types.

Besides its IAP-interacting property, Omi/HtrA2 is also an inducer/accelerator of cell death through its serine protease catalytic domain. When the mature protein, without its mitochondrial presequence, is overexpressed in the cytoplasm, it induces cell death independent of caspase activation or IAP interaction. The catalytic domain is essential for this cytotoxic activity. ${ }^{17-20}$ In addition to its amino-terminal mitochondrial presequence and its catalytic domain, Omi/HtrA2 also has a carboxyterminal PDZ domain. ${ }^{105}$ PDZ domains, an acronym formed by the proteins in which they were first identified (postsynaptic density protein, disc large tumour suppressor and Zo-1 tight junction protein) have been found to be involved in a variety of protein - protein interactions including the assembly of multimeric complexes that can initiate signal transduction at specific subcellular locations, particularly at the cell surface. ${ }^{108,109}$ One group of proteins that is characteristic for the presence of such PDZ modules are MAGUK (membrane-associated guanylate kinase) proteins, a class of proteins that are typically associated with cell junctions or other specialised sites on the plasma membrane. ${ }^{110}$ In this context, the caspase recruitment domain proteins CARD11 and CARD14 were identified as MAGUK family members that interact with the B-cell lymphoma protein $\mathrm{Bcl}-10$ and activate $\mathrm{NF}-\kappa \mathrm{B}$ signalling pathways. ${ }^{111}$ Via its PDZ domain, Omi/HtrA2 was shown to bind Mxi2, an alternatively spliced form of p38 stressactivated kinase ${ }^{112}$ but the function of this interaction is still elusive. Specific physiological substrates for Omi/HtrA2, in the context of cell death, are still unknown and require further investigation. Recently, the crystal structure of Omi/ $\mathrm{HtrA} 2$ was revealed showing that the protein behaves as a homotrimer. ${ }^{113}$ Trimerisation creates a pyramid-shaped structure, with the aminoterminal IAP-binding sequences on top and the PDZ domains at the bottom. Monomeric Omi/HtrA2 mutants are completely inactive showing that trimerisation is essential for protease activity and proper function. However, the IAP-binding motif was shown to be dispensable for its cell-killing activity, in contrast to the PDZ domain that seems to serve as a sensitive regulator of the protease activity in Omi/HtrA2. ${ }^{113}$ Based on these structural and biochemical observations, it was proposed that the homotrimeric Omi/HtrA2 would most likely interact with its PDZ domains with a trimeric assembly. Omi/HtrA2 may so interact with trimeric death receptors, such as TNFR and 
Fas, or other components of the DISC, and by its proteolytic activity contribute to the activation of the apoptotic pathway. ${ }^{113}$

Omi/HtrA2 represents an evolutionarily conserved protease whose bacterial orthologue, the E. coli DegP/HtrA endoprotease, is necessary for bacterial thermo-, oxidative and osmotic tolerance. ${ }^{114}$ At high temperature, bacterial HtrA functions as a protease and at normal temperatures as a chaperone. ${ }^{115}$ These prokaryotic functions could suggest that $\mathrm{Omi} / \mathrm{HtrA} 2$ is a multi-functional protein with protective functions in mitochondria and cytotoxic functions once released into the cytosol. However, the precise function of Omi/HtrA2 in cell death, both caspasedependent as well as caspase-independent, remains elusive and may only be revealed by 'knockin' transgenic studies using mutant forms of $\mathrm{HtrA2/Omi} \mathrm{that} \mathrm{lack} \mathrm{one} \mathrm{of}$ the functional domains.

\section{Endonuclease G}

Endonuclease $\mathrm{G}$, and its homologue cps-6 in C. elegans, ${ }^{116}$ are $30 \mathrm{kDa}$ proteins that contain a mitochondrial localisation signal which is removed after import into the mitochondrial intermembrane space. ${ }^{15,16,117}$ Although originally identified as a protein involved in mitochondrial DNA replication, ${ }^{117}$ endonuclease $G$ was recently shown to be released from mitochondria during apoptosis induced with TNF, agonistic anti-Fas antibodies and UV-irradiation and to translocate to the cell nucleus where it is involved in nuclear DNA breakdown. ${ }^{15,16,116}$ Several DNAses have been implicated in apoptotic DNA degradation. ${ }^{118}$ The best-characterised enzyme is the caspase-activated DNAse CAD/DFF40, ${ }^{119,120}$ that forms an inactive heterodimer with its chaperone and inhibitor, ICAD/DFF45. ${ }^{120,121}$ Upon induction of apoptosis, ICAD is cleaved by caspase- 3 releasing active CAD that can then degrade nuclear DNA. ${ }^{120,121}$ However, ICAD-deficient mice or transgenic mice lacking the ICAD-caspase-3 cleavage sites are phenotypically normal and still show residual DNA fragmentation, ${ }^{122,123}$ indicating that CAD is not the only DNAse implicated in apoptosis. Therefore, it is conceivable that endonuclease $G$ is responsible for the nuclear DNA degradation observed in embryonic fibroblasts from these mice after induction of apoptosis by TNF treatment or ultraviolet radiation. ${ }^{15}$

DNA degradation during apoptosis generally occurs in two stages: first when high molecular weight fragments $(\sim 50 \mathrm{~kb})$ are generated, consistent with the size of chromatin loop domains, and second when oligonucleosomal fragments are formed (so-called 'DNA laddering'). ${ }^{124}$ CAD/DFF40 is dispensable for high molecular weight DNA cleavage and early stage chromatin condensation, but it is essential for final chromatin condensation, and oligonucleosomal fragmentation. ${ }^{125}$ Although Wang and colleagues showed endonuclease G-dependent DNA 'laddering', 15,126 we could only observe higher order DNA degradation in isolated nuclei. ${ }^{16}$ The role of endonuclease $G$ in apoptosis is further questioned by the high concentration required to induce DNA degradation in vitro as compared to CAD/ DFF40 (100 times more endonuclease $G$ is required than CAD). ${ }^{15,121}$ Probably, endonuclease $G$ alone is not sufficient, but requires other nucleases or cofactors. In this context, it was shown that both exonucleases and DNAse I facilitate the ability of endonuclease $G$ to generate DNA cleavage products, suggesting that, in vivo, these activities work in concert to ensure efficient DNA breakdown in apoptotic cells. ${ }^{126}$ Unlike CAD/DFF40, endonuclease Ginduced DNA degradation was shown to be independent of caspase activation, ${ }^{15,16}$ as is also the case for AIF. ${ }^{12}$ AIF, however, is not a self-nuclease while endonuclease $G$ is. It is also possible that both proteins do not act in isolation but require each other for full activity. Both proteins may ensure nuclear degradation when caspase activation is limited or compromised, as may be the case during viral infection. ${ }^{127,128}$ or they may be responsible for the caspaseindependent DNA degradation that has been observed in plants, fungi and protozoa. ${ }^{88,129}$

\section{Other}

Besides their localisation in the cytoplasm, the mitochondrial intermembrane space has also been reported to contain a subpopulation of procaspases $(-2,-3,-8,-9)$, at least in certain cell types. Upon apoptotic permeabilisation of the outer mitochondrial membrane, such procaspases are released from mitochondria into the cytosol generating enzymatically active caspases, either through the apoptosome (for procaspase-3 and -9) or via unknown mechanisms (for procaspase-2 and -8). ${ }^{130-134}$ Also, active caspase-7 was shown to be associated with the mitochondrial fraction. ${ }^{135}$ More recently, mature processed caspase- 9 was also identified in mitochondria of non-apoptotic cells, although this seems to be a cell type-specific phenomenon. ${ }^{136}$ Upon induction of apoptosis, this processed caspase- 9 is released from mitochondria and becomes active in the presence of its co-activators Apaf-1 and cytochrome $c$. The mitochondrial localisation of caspases remains controversial for several reasons. Using purified mitochondria from different cell sources, we could not identify any procaspase or active caspase in this mitochondrial fraction by Western blotting (van Loo et al., in preparation). Moreover, using the PSORT database (http://psort.nibb.ac.jp), no mitochondrial localisation signal could be identified in any of the caspases except for procaspase-2.

Using a proteomics approach, we and others have identified proteins that are released from purified mitochondria treated with recombinant $\mathrm{tBid}$ or atractyloside. ${ }^{137,138}$ Apart from AIF, which could only be identified in the mitochondrial supernatant of tBid-treated mitochondria using a specific antiserum ( $G$ van Loo and $P$ Vandenabeele, unpublished results), and the caspases, which were not detectable by Western blotting, all of the mitochondrial proteins described above were identified in the supernatant of tBid-treated mitochondria. Some other promising factors were also found, but their exact function in cell death is still elusive. ${ }^{137,138} \mathrm{~A}$ remarkable link with the previously discussed role of tBid in phospholipid transfer is the release of the fatty acid-binding protein (FABP), which binds free fatty acids and may be implicated in intracellular lipid transport. Acyl-CoA-binding protein, the endogenous ligand of the mitochondrial benzodiazepine receptor, is 
involved in acetyl-CoA ester transport and was reported to cause opening of the PTP after ligation with its receptor, thus favouring apoptosis. ${ }^{139}$ Furthermore, we identified the translocase of the inner mitochondrial membrane TIMM13b, a protein implicated in protein import from the cytoplasm into the mitochondrial inner membrane. Another member of this family, the $\mathrm{X}$-linked deafness-dystonia protein (also called TIMM8a) ${ }^{140}$ has already been described as being released from the intermembrane mitochondrial space after treatment with atractyloside. ${ }^{138}$

An important question in this story of mitochondrial protein efflux concerns the kinetics of release. Using a range of cytotoxic drugs and DNA damaging agents, Adrain et al. recently demonstrated that, in contrast to cytochrome $c$ efflux, Smac/DIABLO release from mitochondria is largely attenuated by inhibition of caspases. This suggests that Smac/DIABLO release is a caspase catalysed event occurring downstream of cytochrome $c$ translocation. ${ }^{141}$ Cytochrome $c$ release would function as an initial trigger in the formation of the apoptosome leading to a caspasedependent positive feedback loop resulting in generalised mitochondrial destruction facilitating the release of Smac/ DIABLO. However, an opposite sequence of release, Smac/DIABLO followed by cytochrome $c$, has also been reported following TRAIL-induced apoptosis (MacFarlane et al., in press). Although the precise mechanism of cytochrome $c$ release is still unclear, it seems to occur in a two-step process representing loosely and tightly bound pools of cytochrome $c .^{10}$ The latter pool represents cytochrome $c$ associated with cardiolipin. ${ }^{142}$ Cardiolipin is an acidic phospholipid that is synthesised in the mitochondria and its expression pattern is confined to the inner mitochondrial membrane and the mitochondrial contact sites. ${ }^{143}$ Lipid peroxidation may mediate the transition from the tightly to the loosely bound pool of cytochrome $c$, which is then released by a Bax-dependent mechanism. ${ }^{10}$ Further studies will be required to evaluate whether or not a hierarchical model exists of mitochondrial protein release and whether differential molecular thresholds exist for the release of these proteins.

\section{Concluding remarks and future perspectives}

Several mitochondrial proteins have recently been shown to become toxic moieties when mitochondrial integrity is compromised. This is often the initiating event for caspase-dependent and caspase-independent mechanisms of cell death. Cytochrome $c$ and Smac/DIABLO induce cellular damage by amplifying caspase-mediated proteolysis. Omi/HtrA2 may neutralise IAP proteins but also contributes as a caspase-independent proteolytic agent. AIF and endonuclease $G$ are both involved in caspaseindependent nuclear DNA disintegration. Under healthy conditions, each of these proteins seems to have a mundane, but essential, role in normal mitochondrial function and cell survival. Cytochrome $c$ and AIF have an electron acceptor/donor (oxidoreductase) function in mitochondrial oxidative phosphorylation; endonuclease $G$ was suggested to be involved in mitochondrial DNA replication (although this activity is controversial as it does not agree with an intermembrane localisation) and the serine protease Omi/HtrA2 is implicated in mitochondrial control of cell protein stability under osmotic, thermal and oxidative stress conditions. However, as yet, no mitochondrial function has been described for Smac/ DIABLO. Following an apoptotic insult, each of these proteins is released into the cytosol where they become cytotoxic agents participating in the destruction of the cell. In this way, mitochondria possess an autonomic system, viz. an arsenal of innocent essential molecules required for mitochondrial (and cellular) homeostasis that, once released into the cytosol, become deadly weapons that push the balance towards cell death.

Although the mitochondrial events in apoptosis have been documented for a wide variety of stimuli, the relative contribution of the different mitochondrial factors in the apoptotic process remains to be determined. It is still unclear whether the homeostatic functions of cytochrome $c$ and AIF in oxidative phosphorylation are required for their proapoptotic activity after relocalization. A 'knockin' animal of cytochrome $c$ or AIF only possessing their oxidative phosphorylation function will shed light on the precise contribution of these mitochondrial factors to the apoptotic process in the context of developmental cell death. Also for the other factors such as Smac/DIABLO and $\mathrm{Omi} / \mathrm{HtrA} 2$ the contribution of the IAP binding motif to the propagation of apoptotic cell death will only become clear by 'knockin' studies with mutants that lack this motif. Moreover, their role as essential components in the apoptotic machinery will only be revealed by genetic deletion of the corresponding genes. Targeted disruption of Smac/DIABLO in vivo has no effect on apoptosis, possibly because Omi/HtrA2 is still fully active. ${ }^{104}$ Double mutant mice, lacking both Smac/DIABLO and Omi/HtrA2, could hopefully clarify their physiological role in apoptotic cell death. Another important issue is the relative contribution of caspase-dependent and caspase-independent mechanisms in cytotoxicity. Do the caspaseindependent pathways such as AIF, HtrA2/Omi and endonuclease G form a 'second line' of cytotoxic capability in cases where the enzymatic activity of caspases is compromised? If so, then it is important to identify these conditions of reduced or inappropriate caspase activity. It has been reported that viral infection, $^{127,128}$ nitrosylation $^{144,145}$ and ATP depletion ${ }^{146}$ negatively influence caspase activity.

In this overview we have raised many questions concerning the contribution of mitochondrial factors to caspase-dependent and caspase-independent pathways leading to cell death. Nonetheless, the last decade of cell death research has contributed substantially to identifying a completely new and additional role for mitochondria, which apart from being suppliers of new energy are also sensors and regulators of cell death. As is generally true for other areas of molecular cell biology, assessing the relative contribution of these different pathways remains the toughest problem to solve. Also, the biochemical mechanism leading to mitochondrial dysfunction and release of mitochondrial factors is still not clear and requires further 
investigation. Hopefully these questions will be solved in a near future, permitting a general view on the mechanism by which mitochondria regulate apoptosis. From a therapeutic point of view, this knowledge would allow the rational design and use of specific synthetic molecules that mimic Bcl-2-like proteins, IAP-binding factors or the action mode of Smac $\beta$. These molecules may not necessarily provoke apoptosis, but they might sensitise cells to apoptotic stimuli, allowing more efficient cancer therapies. On the other hand strategies that block the proapoptotic activities of BH3-only proteins at premitochondrial levels may allow decreased damage after ischaemia-reperfusion.

\section{Acknowledgements}

$G$ van Loo is a predoctoral researcher with the Flanders Interuniversity Institute for Biotechnology, $X$ Saelens is supported by the Biotech fund and $M$ van Gurp is a fellow with the Vlaams Instituut voor de B evordering van het Wetenschappelijk-technologisch Onderzoek in de Industrie and received a grant from the Centrum voor Studie en Behandeling van Gezwelziekten. This work was supported in part by the Interuniversitaire Attractiepolen V, the Fonds voor Wetenschappelijk OnderzoekVlaanderen (grant 3G.0006.01), the Bijzonder Onderzoeksfonds, an EC-RTD grant QLG1-CT-1999-00739, an RUG-cofinanciering EU project (011C0300), and an RUG-GOA project (12050502).

\section{References}

1. Budihardjo I, Oliver H, Lutter M, Luo W and Wang X (1999) Biochemical pathways of caspase activation during apoptosis. Annu. Rev. Cell Dev. Biol. 15 $269-290$

2. Zamzami N, Marchetti P, Castedo M, Decaudin D, Macho A, Hirsch T, Susin SA, Petit PX, Mignotte B and Kroemer G (1995) Sequential reduction of mitochondrial transmembrane potential and generation of reactive oxygen species in early programmed cell death. J. Exp. Med. 182: 367-377

3. Kroemer G, Petit P, Zamzami N, Vayssiere JL and Mignotte B (1995) The biochemistry of programmed cell death. FASEB J. 9: 1277-1287

4. Liu X, Kim CN, Yang J, Jemmerson R and Wang X (1996) Induction of apoptotic program in cell-free extracts: requirement for dATP and cytochrome c. Cell 86: $147-157$

5. Wei MC, Lindsten T, Mootha VK, Weiler S, Gross A, Ashiya M, Thompson CB and Korsmeyer SJ (2000) tBID, a membrane-targeted death ligand, oligomerizes BAK to release cytochrome c. Genes Dev. 14: 2060-2071

6. Shimizu Sand Tsujimoto Y (2000) Proapoptotic BH3-only Bcl-2 family members induce cytochrome $\mathrm{c}$ release, but not mitochondrial membrane potential loss, and do not directly modulate voltage-dependent anion channel activity. Proc. Natl. Acad. Sci. USA 97: 577-582

7. von Ahsen O, Renken C, Perkins G, Kluck RM, Bossy-Wetzel E and Newmeyer DD (2000) Preservation of mitochondrial structure and function after Bid- or Bax- mediated cytochrome c release. J. Cell Biol. 150: 1027-1036

8. Mootha VK, Wei MC, Buttle KF, Scorrano L, Panoutsakopoulou V, Mannella CA and Korsmeyer SJ (2001) A reversible component of mitochondrial respiratory dysfunction in apoptosis can be rescued by exogenous cytochromec. EMBO J. 20: $661-671$

9. Leist M, Single B, Castoldi AF, Kuhnle S and Nicotera P (1997) Intracellular adenosine triphosphate (ATP) concentration: a switch in the decision between apoptosis and necrosis. J. Exp. Med. 185: 1481-1486

10. Ott M, Robertson JD, Gogvadze V, Zhivotovsky B and Orrenius S (2002) Cytochrome $\mathrm{c}$ release from mitochondria proceeds by a two-step process. Proc. Natl. Acad. Sci. USA 99: 1259-1263

11. Scorrano L, Ashiya M, Buttle K, Weiler S, Oakes SA, Mannella CA and Korsmeyer SJ (2002) A distinct pathway remodels mitochondrial cristae and mobilizes cytochrome c during apoptosis. Dev. Cell 2: 55-67
12. Susin SA, Lorenzo HK, Zamzami N, Marzol, Snow BE, Brothers GM, Mangion J Jacotot E, Costantini P, Loeffler M, Larochette N, Goodlett DR, Aebersold R, Siderovski DP, Penninger JM and Kroemer G (1999) Molecular characterization of mitochondrial apoptosis-inducing factor. Nature 397: 441-446

13. Verhagen AM, Ekert PG, Pakusch M, Silke J, Connolly LM, Reid GE, Moritz RL, Simpson RJ and VauxDL (2000) Identification of DIABLO, a mammalian protein that promotes apoptosis by binding to and antagonizing IAP proteins. Cell 102 43-53

14. Du C, Fang M, Li Y, Li L and Wang X (2000) Smac, a mitochondrial protein that promotes cytochrome $c$-dependent caspase activation by eliminating IAP inhibition. Cell 102: 33-42

15. Li LY, Luo $X$ and Wang $X$ (2001) Endonuclease $G$ is an apoptotic DNase when released from mitochondria. Nature 412: $95-99$

16. van Loo G, Schotte P, van Gurp M, Demol H, Hoorelbeke B, Gevaert K, Rodriguez I, Ruiz-Carrillo A, Vandekerckhove J, Declercq W, Beyaert R and Vandenabeele $P$ (2001) Endonuclease G: a mitochondrial protein released in apoptosis and involved in caspase-independent DNA degradation. Cell Death Differ. 8: $1136-1142$

17. Suzuki Y, ImaiY, Nakayama H, Takahashi K, Takio Kand Takahashi R(2001)A serine protease, $\mathrm{HtrA}$, is released from the mitochondria and interacts with XIAP, inducing cell death. Mol. Cell 8: 613-621

18. Martins LM, laccarino I, Tenev T, Gschmeissner S, Totty NF, Lemoine NR, Savopoulos J, Gray CW, Creasy CL, Dingwall C and Downward J (2002) The serine protease Omi/HtrA2 regulates apoptosis by binding XIAP through a reaper-like motif. J. Biol. Chem. 277: 439-444

19. Hegde R, Srinivasula SM, Zhang Z, Wassell R, Mukattash R, Cilenti L, DuBois G, Lazebnik Y, Zervos AS, Fernandes-Alnemri T and Alnemri ES (2002) Identification of Omi/HtrA2 as a mitochondrial apoptotic serine protease that disrupts inhibitor of apoptosis protein-caspase interaction. J. Biol. Chem. 277: $432-438$

20. Verhagen AM, Silke J, Ekert PG, Pakusch M, Kaufmann H, Connolly LM, Day CL, Tikoo A, Burke R, Wrobel C, Moritz RL, Simpson RJ and Vaux DL (2002) $\mathrm{HtrA} 2$ promotes cell death through its serine protease activity and its ability to antagonize inhibitor of apoptosis proteins. J. Biol. Chem. 277: 445-454

21. van Loo G, van Gurp M, Depuydt B, Srinivasula SM, Rodriguez I, Alnemri ES, Gevaert K, Vandekerckhove J, Declercq W and Vandenabeele P (2002) The serine protease $\mathrm{Omi} / \mathrm{Htr} \mathrm{A} 2$ is released from mitochondria during apoptosis. Omi/HtrA2 interacts with caspase-inhibitor XIAP and induces enhanced caspase activity. Cell Death Differ. 9: 20-27

22. Ferri KF and Kroemer G (2001) Organelle-specific initiation of cell death pathways. Nat. Cell Biol. 3: E255-E263

23. Herr I and Debatin KM (2001) Cellular stress response and apoptosis in cancer therapy. Blood 98: 2603-2614

24. Costantini P, Jacotot E, Decaudin D and Kroemer G (2000) Mitochondrion as a novel target of anticancer chemotherapy. J. Natl. Cancer Inst. 92: 1042-1053

25. Krammer PH (2000) CD95's deadly mission in the immune system. Nature 407: $789-795$

26. Luo X, Budihardjo I, Zou H, Slaughter C and Wang X (1998) Bid, a Bcl2 interacting protein, mediates cytochrome $c$ release from mitochondria in response to activation of cell surface death receptors. Cell 94: 481-490

27. Li H, Zhu H, Xu CJ and Yuan J (1998) Cleavage of BID by caspase 8 mediates the mitochondrial damage in the Fas pathway of apoptosis. Cell 94: 491-501

28. Zha J, Weiler S, Oh KJ, Wei MC and Korsmeyer SJ (2000) Posttranslational Nmyristoylation of BID as a molecular switch for targeting mitochondria and apoptosis. Science 290: 1761-1765

29. Lutter M, Fang M, Luo X, Nishijima M, Xie X and Wang X (2000) Cardiolipin provides specificity for targeting of tBid to mitochondria. Nat. Cell Biol. 2: $754-$ 761

30. Lutter M, Perkins GA and Wang X (2001) The pro-apoptotic Bcl-2 family member tBid localizes to mitochondrial contact sites. BMC Cell Biol. 2: 22

31. Gross A, Yin XM, Wang K, Wei MC, JockelJ, Milliman C, Erdjument-Bromage H, Tempst $P$ and Korsmeyer SJ (1999) Caspase cleaved BID targets mitochondria and is required for cytochrome $c$ release, while $B C L-X L$ prevents this release but not tumor necrosis factor-R1/Fas death. J. Biol. Chem. 274: 1156-1163

32. Heibein JA, Goping IS, Barry M, Pinkoski MJ, Shore GC, Green DR and Bleackley RC (2000) Granzyme B-mediated cytochrome c release is regulated by the Bcl-2 family members bid and Bax. J. Exp. Med. 192: 1391-1402 
33. Barry M, Heibein JA, Pinkoski MJ, Lee SF, Moyer RW, Green DR and Bleackley RC (2000) Granzyme B short-circuits the need for caspase 8 activity during granule-mediated cytotoxic T-lymphocyte killing by directly cleaving Bid. Mol. Cell. Biol. 20: 3781-3794

34. Sutton VR, Davis JE, Cancilla M, Johnstone RW, Ruefli AA, Sedelies K, Browne $\mathrm{KA}$ and Trapani JA (2000) Initiation of apoptosis by granzyme $B$ requires direct cleavage of bid, but not direct granzyme B-mediated caspase activation. J. Exp. Med. 192: 1403-1414

35. Alimonti JB, Shi L, Baijal PK and Greenberg AH (2001) Granzyme B induces BID-mediated cytochrome c release and mitochondrial permeability transition J. Biol. Chem. 276: 6974-6982

36. Thomas DA, Scorrano L, Putcha GV, Korsmeyer SJ and Ley TJ (2001) Granzyme B can cause mitochondrial depolarization and cell death in the absence of BID, BAX, and BAK. Proc. Natl. Acad. Sci. USA 98: 14985-14990

37. Stoka V, Turk B, Schendel SL, Kim TH, Cirman T, Snipas SJ, Ellerby LM, Bredesen D, Freeze H, Abrahamson M, Bromme D, Krajewski S, Reed JC, Yin XM, Turk V and Salvesen GS (2001) Lysosomal protease pathways to apoptosis. Cleavage of bid, not procaspases, is the most likely route. J. Biol. Chem. 276: 3149-3157

38. Chen M, He H, Zhan S, Krajewski S, Reed JC and Gottlieb RA (2001) Bid is cleaved by calpain to an active fragment in vitro and during myocardial ischemia/reperfusion. J. Biol. Chem. 276: 30724-30728

39. Yin XM, Wang K, Gross A, Zhao Y, Zinkel S, Klocke B, Roth KA and Korsmeyer SJ (1999) Bid-deficient mice are resistant to Fas-induced hepatocellular apoptosis. Nature 400: 886-891

40. Ranger AM, Malynn BA and Korsmeyer SJ (2001) Mouse models of cell death Nat. Genet. 28: 113-118

41. Wei MC, Zong WX, Cheng EH, Lindsten T, Panoutsakopoulou V, Ross AJ, Roth KA, MacGregor GR, Thompson CB and Korsmeyer SJ (2001) Proapoptotic $B A X$ and BAK: a requisite gateway to mitochondrial dysfunction and death. Science 292: 727-730

42. Gross A, McDonnell JM and Korsmeyer SJ (1999) BCL-2 family members and the mitochondria in apoptosis. Genes Dev. 13: 1899-1911

43. Adams JMand Cory S (2001) Life-or-death decisions by the Bcl-2 protein family. Trends Biochem. Sci. 26: 61-66

44. Puthalakath $\mathrm{H}$ and Strasser $\mathrm{A}$ (2002) Keeping killers on a tight leash: transcriptional and post-translational control of the pro-apoptotic activity of BH3-only proteins. Cell Death Differ. 9: 505-512

45. Martinou JC and Green DR (2001) Breaking the mitochondrial barrier. Nat. Rev. Mol. Cell. Biol. 2: 63-67

46. Zamzami N and Kroemer G (2001) The mitochondrion in apoptosis: how Pandora's box opens. Nat. Rev. Mol. Cell. Biol. 2: 67-71

47. Marzo I, BrennerC, Zamzami N, Jurgensmeier JM, Susin SA, Vieira HL, Prevost MC, Xie Z, Matsuyama S, Reed JC and Kroemer G (1998) Bax and adenine nucleotide translocator cooperate in the mitochondrial control of apoptosis. Science 281: 2027-2031

48. Shimizu S, Narita M and Tsujimoto Y (1999) Bcl-2 family proteins regulate the release of apoptogenic cytochrome $\mathrm{c}$ by the mitochondrial channel VDAC. Nature 399: 483-487

49. Fesik SW (2000) Insights into programmed cell death through structura biology. Cell 103: 273-282

50. Schendel SL, Azimov R, Pawlowski K, Godzik A, Kagan BL and Reed JC (1999) Ion channel activity of the $\mathrm{BH} 3$ only Bcl-2 family member, BID. J. Biol. Chem. 274: $21932-21936$

51. Eskes R, Desagher S, Antonsson B and Martinou JC (2000) Bid induces the oligomerization and insertion of Bax into the outer mitochondrial membrane. Mol. Cell. Biol. 20: 929-935

52. Suzuki M, Youle RJ and Tjandra N (2000) Structure of Bax: coregulation of dimer formation and intracellular localization. Cell 103: 645-654

53. Cheng EH, Wei MC, Weiler S, Flavell RA, Mak TW, Lindsten T and Korsmeyer SJ (2001) BCL-2, BCL-X(L) sequester BH3 domain-only molecules preventing BAX- and BAK-mediated mitochondrial apoptosis. Mol. Cell 8: 705-711

54. Zong WX, Lindsten T, Ross AJ, MacGregor GR and Thompson CB (2001) BH3only proteins that bind pro-survival Bcl-2 family members fail to induce apoptosis in the absence of Bax and Bak. Genes Dev. 15: 1481-1486

55. Chai J, Du C, Wu JW, Kyin S, Wang X and Shi Y (2000) Structural and biochemical basis of apoptotic activation by Smac/DIABLO. Nature 406: 855862
56. Pavlov EV, Priault M, Pietkiewicz D, Cheng EH, Antonsson B, Manon S, Korsmeyer SJ, Mannella CA and Kinnally KW (2001) A novel, high conductance channel of mitochondria linked to apoptosis in mammalian cells and Bax expression in yeast. J. Cell Biol. 155: 725-731

57. Esposti MD, Erler JT, Hickman JA and Dive C (2001) Bid, a widely expressed proapoptotic protein of the Bcl-2 family, displays lipid transfer activity. Mol. Cell. Biol. 21: 7268-7276

58. Jaattela M, Benedict M, Tewari M, Shayman JA and Dixit VM (1995) Bcl-x and $\mathrm{Bcl}-2$ inhibit TNF and Fas-induced apoptosis and activation of phospholipase A2 in breast carcinoma cells. Oncogene 10: 2297-2305

59. Esposti MD (2002) Lipids, cardiolipin and apoptosis: a greasy licence to kill. Cell Death Differ. 9: 234-236

60. Zhivotovsky B, Orrenius S, Brustugun OT and Doskeland SO (1998) Injected cytochrome $c$ induces apoptosis. Nature 391: $449-450$

61. LiP, Nijhawan D, Budihardjol, Srinivasula SM, Ahmad M, Alnemri ES and Wang X (1997) Cytochrome $c$ and dATP-dependent formation of Apaf-1/caspase-9 complex initiates an apoptotic protease cascade. Cell 91: 479-489

62. Zou H, Henzel WJ, Liu X, Lutschg A and Wang X (1997) Apaf-1, a human protein homologous to $\mathrm{C}$-elegans CED-4, participates in cytochrome c-dependent activation of caspase-3. Cell 90: 405-413

63. Cain K, Brown DG, Langlais C and Cohen GM (1999) Caspase activation involves the formation of the aposome, a large (approximately $700 \mathrm{kDa}$ ) caspase-activating complex. J. Biol. Chem. 274: 22686-22692

64. Cain K, Bratton SB, Langlais C, Walker G, Brown DG, Sun XM and Cohen GM (2000) Apaf-1 oligomerizes into biologically active approximately 700-kDa and inactive approximately 1.4-MDa apoptosome complexes. J. Biol. Chem. 275: 6067-6070

65. Slee EA, Harte MT, Kluck RM, WolfBB, Casiano CA, Newmeyer DD, Wang HG, Reed JC, Nicholson DW, Alnemri ES, Green DR and Martin SJ (1999) Ordering the cytochrome c-initiated caspase cascade: hierarchical activation of caspases-2, -3, -6, -7, -8, and -10 in a caspase-9-dependent manner. J. Cell Biol. 144: 281-292

66. Van de Craen M, Declercq W, Van den brande I, Fiers W and Vandenabeele $P$ (1999) The proteolytic procaspase activation network: an in vitro analysis. Cell Death Differ. 6: 1117-1124

67. Srinivasula SM, Ahmad M, Fernandes-Alnemri T and Alnemri ES (1998) Autoactivation of procaspase-9 by Apaf-1-mediated oligomerization. Mol. Cell 1: $949-957$

68. Acehan D, Jiang X, Morgan DG, Heuser JE, Wang X and Akey CW (2002) Three-dimensional structure of the apoptosome: implications for assembly, procaspase-9 binding, and activation. Mol. Cell 9: 423-432

69. Cain K, Bratton SB and Cohen GM (2002) The Apaf-1 apoptosome: a large caspase-activating complex. Biochimie 9: 203-214

70. Jiang $X$ and Wang $X(2000)$ Cytochrome $c$ promotes caspase- 9 activation by inducing nucleotide binding to Apaf-1. J. Biol. Chem. 275: 31199-31203

71. Neer EJ, Schmidt CJ, Nambudripad R and Smith TF (1994) The ancient regulatory-protein family of WD-repeat proteins. Nature 371: 297-300

72. Benedict MA, Hu Y, Inohara N and Nunez G (2000) Expression and functional analysis of Apaf- 1 isoforms. Extra Wd-40 repeat is required for cytochrome $\mathrm{C}$ binding and regulated activation of procaspase-9. J. Biol. Chem. 275: 84618468

73. Hu Y, Benedict MA, Ding L and Nunez G (1999) Role of cytochrome c and dATP/ ATP hydrolysis in Apaf-1-mediated caspase-9 activation and apoptosis. EMBO J. 18: $3586-3595$

74. Adrain C, Slee EA, Harte MT and Martin SJ (1999) Regulation of apoptotic protease activating factor- 1 oligomerization and apoptosis by the WD-40 repeat region. J. Biol. Chem. 274: 20855-20860

75. Yu T, Wang X, Purring-Koch C, Wei Y and McLendon GL (2001) A mutational epitope for cytochrome $\mathrm{C}$ binding to the apoptosis protease activation factor-1. J. Biol. Chem. 276: 13034-13038

76. KluckRM, Martin SJ, Hoffman BM, ZhouJS, Gren DR and Newmeyer DD (1997) Cytochrome $c$ activation of CPP32-like proteolysis plays a critical role in a Xenopus cell-free apoptosis system. EMBO J. 16: 4639-4649

77. Abdullaev Z, Bodrova ME, Chernyak BV, Dolgikh DA, Kluck RM, Pereverzev MO, Arseniev AS, Efremov RG, Kirpichnikov MP, Mohkova EN, Newmeyer DD, Roder $\mathrm{H}$ and Skulachev VP (2002) A cytochrome c mutant with high electron transfer and antioxidant activities but devoid of apoptogenic effect. Biochem. J. 362: $749-754$ 
78. Li K, Li Y, Shelton JM, Richardson JA, Spencer E, Chen ZJ, Wang X and Williams RS (2000) Cytochrome c deficiency causes embryonic lethality and attenuates stress-induced apoptosis. Cell 101: 389-399

79. Cecconi F, Alvarez-Bolado G, Meyer BI, Roth KA and Gruss P (1998) Apaf-1 (CED-4 homolog) regulates programmed cell death in mammalian development. Cell 94: 727-737

80. Yoshida H, Kong YY, Yoshida R, Elia AJ, Hakem A, Hakem R, Penninger JM and Mak TW (1998) Apaf1 is required for mitochondrial pathways of apoptosis and brain development. Cell 94: 739-750

81. Hakem R, Hakem A, Duncan GS, Henderson JT, Woo M, Soengas MS, Elia A, de la Pompa JL, Kagi D, Khoo W, Potter J, Yoshida R, Kaufman SA, Lowe SW, Penninger JM and Mak TW (1998) Differential requirement for caspase 9 in apoptotic pathways in vivo. Cell 94: 339-352

82. Kuida K, Haydar TF, Kuan CY, Gu Y, Taya C, Karasuyama H, Su MS, Rakic P and Flavell RA (1998) Reduced apoptosis and cytochrome c-mediated caspase activation in mice lacking caspase 9. Cell 94: $325-337$

83. Joza N, Susin SA, Daugas E, Stanford WL, Cho SK, Li CY, Sasaki T, Elia AJ, Cheng HY, Ravagnan L, Ferri KF, Zamzami N, Wakeham A, Hakem R, Yoshida $\mathrm{H}$, Kong YY, Mak TW, Zuniga-PfluckerJC, Kroemer Gand Penninger JM (2001) Essential role of the mitochondrial apoptosis-inducing factor in programmed cell death. Nature 410: 549-554

84. Susin SA, Daugas E, Ravagnan L, Samejima K, Zamzami N, Loeffler M, Costantini P, Ferri KF, Irinopoulou T, Prevost MC, Brothers G, Mak TW Penninger J, Earnshaw WC and Kroemer G (2000) Two distinct pathways leading to nuclear apoptosis. J. Exp. Med. 192: 571-580

85. Miramar MD, Costantini P, Ravagnan L, Saraiva LM, Haouzi D, Brothers G, Penninger JM, Peleato ML, Kroemer G and Susin SA (2001) NADH oxidase activity of mitochondrial apoptosis-inducing factor. J. Biol. Chem. 276: 16391 16398

86. Ravagnan L, Gurbuxani S, Susin SA, Maisse C, Daugas E, Zamzami N, Mak T, Jaattela M, Penninger JM, Garrido C and Kroemer G (2001) Heat-shock protein 70 antagonizes apoptosis-inducing factor. Nat. Cell Biol. 3: 839-843

87. Coucouvanis E and Martin GR (1995) Signals for death and survival: a two-step mechanism for cavitation in the vertebrate embryo. Cell 83: 279-287

88. Lorenzo HK, Susin SA, Penninger J and Kroemer G (1999) Apoptosis inducing factor (AIF): a phylogenetically old, caspase-independent effector of cell death. Cell Death Differ. 6: 516-524

89. Bratton SB, Walker G, Srinivasula SM, Sun XM, Butterworth M, Alnemri ES and Cohen GM (2001) Recruitment, activation and retention of caspases-9 and -3 by Apaf- 1 apoptosome and associated XIAP complexes. EMBO J. 20: $998-$ 1009

90. Srinivasula SM, Hegde R, Saleh A, DattaP, ShiozakiE, Chai J, Lee RA, Robbins PD, Fernandes-Alnemri T, Shi Y and Alnemri ES (2001) A conserved XIAPinteraction motif in caspase- 9 and Smac/DIABLO regulates caspase activity and apoptosis. Nature 410: $112-116$

91. LiuZ, Sun C, Olejniczak ET, Meadows RP, Betz SF, Oost T, Herrmann J, Wu JC and Fesik SW (2000) Structural basis for binding of Smac/DIABLO to the XIAP BIR3 domain. Nature 408: 1004-1008

92. Wu G, Chai J, Suber TL, Wu JW, Du C, Wang Xand Shi Y (2000) Structural basis of IAP recognition by Smac/DIABLO. Nature 408: 1008-1012

93. Chai J, Shiozaki E, Srinivasula SM, Wu Q, Datta P, Alnemri ES, Shi Y and Dataa $P(2001)$ Structural basis of caspase-7 inhibition by XIAP. Cell 104: 769-780

94. Huang Y, Park YC, Rich RL, Segal D, Myszka DG and Wu H (2001) Structural basis of caspase inhibition by XIAP: differential roles of the linkerversus the BIR domain. Cell 104: 781-790

95. Riedl SJ, Renatus M, Schwarzenbacher R, Zhou Z, Sun C, Fesik SW Liddington RC and Salvesen GS (2001) Structural basis for the inhibition of caspase-3 by XIAP. Cell 104: 791-800

96. Wu JW, Cocina AE, Chai J, Hay BA and Shi Y (2001) Structural analysis of a functional DIAP1 fragment bound to grim and hid peptides. Mol. Cell 8: 95-104

97. Vucic D, Kaiser WJ and Miller LK (1998) Inhibitor of apoptosis proteins physically interact with and block apoptosis induced by Drosophila proteins HID and GRIM. Mol. Cell. Biol. 18: 3300-3309

98. Wang SL, Hawkins CJ, Yoo SJ, Muller HA and Hay BA (1999) The Drosophila caspase inhibitor DIAP1 is essential for cell survival and is negatively regulated by HID. Cell 98: $453-463$

99. Goyal L, McCall K, Agapite J, Hartwieg E and Steller H (2000) Induction of apoptosis by Drosophila reaper, hid and grim through inhibition of IAP function. EMBO J. 19: 589-597
100. Srinivasula SM, Datta P, Kobayashi M, Wu JW, Fujioka M, Hegde R, Zhang Z, Mukattash R, Fernandes-Alnemri T, Shi Y, Jaynes JB and Alnemri ES (2002) Sickle, a novel drosophila death gene in the reaper/hid/grim region, endodes an IAP-inhibitory protein. Curr. Biol. 12: 125-130

101. Wing JP, Karres JS, Ogdahl JL, Zhou L, Schwartz LM and Nambu JR (2002) Drosophila sickle is a novel grim-reaper cell death activator. Curr. Biol. 12: $131-135$

102. Christich A, Kauppila S, Chen P, Sogame N, Ho SI and Abrams JM (2002) The damage-responsive Drosophila gene sickle encodes a novel IAP binding protein similar to but distinct from reaper, grim, and hid. Curr. Biol. 12: 137-140

103. Roberts DL, Merrison W, MacFarlane M and Cohen GM (2001) The inhibitor of apoptosis protein-binding domain of $\mathrm{Smac}$ is not essential for its proapoptotic activity. J. Cell Biol. 153: 221-228

104. Okada H, Suh WK, Jin J, Woo M, Du C, Elia A, Duncan GS, Wakeham A, Itie A, Lowe SW, Wang X and Mak TW (2002) Generation and characterization of Smac/DIABLO-deficient mice. Mol. Cell. Biol. 22: 3509-3517

105. Faccio L, Fusco C, Chen A, Martinotti S, Bonventre JV and Zervos AS (2000) Characterization of a novel human serine protease that has extensive homology to bacterial heat shock endoprotease $\mathrm{HtrA}$ and is regulated by kidney ischemia. J. Biol. Chem. 275: 2581-2588

106. Gray CW, Ward RV, Karran E, Turconi S, Rowles A, Viglienghi D, Southan C Barton A, Fantom KG, West A, Savopoulos J, Hassan NJ, Clinkenbeard H, Hanning C, Amegadzie B, Davis JB, Dingwall C, Livi GP and Creasy CL (2000) Characterization of human HtrA2, a novel serine protease involved in the mammalian cellular stress response. Eur. J. Biochem. 267: 5699-5710

107. Savopoulos JW, CarterPS, Turconi S, Pettman GR, KarranEH, Gray CW, Ward RV, Jenkins $O$ and Creasy $C L$ (2000) Expression, purification, and functional analysis of the human serine protease HtrA2. Protein Expr. Purif. 19: 227-234

108. Fanning AS and Anderson JM (1996) Protein-protein interactions: PDZ domain networks. Curr. Biol. 6: 1385-1388

109. Songyang Z, Fanning AS, Fu C, Xu J, Marfatia SM, Chishti AH, Crompton A, Chan AC, Anderson JM and Cantley LC (1997) Recognition of unique carboxylterminal motifs by distinct PDZ domains. Science 275: 73-77

110. Fanning AS and Anderson JM (1999) Protein modules as organizers of membrane structure. Curr. Opin. Cell Biol. 11: 432-439

111. Bertin J, Wang L, Guo Y, Jacobson MD, Poyet JL, Srinivasula SM, Merriam S, DiStefano PS and Alnemri ES (2001) CARD11 and CARD14 are novel caspase recruitment domain (CARD)/membrane-associated guanylate kinase (MAGUK) family members that interact with BCL10 and activate NF-kappa B. J. Biol. Chem. 276: 11877-11882

112. Zervos AS, Faccio L, Gatto JP, Kyriakis JM and BrentR (1995) Mxi2, a mitogenactivated protein kinase that recognizes and phosphorylates Max protein. Proc. Natl. Acad. Sci. USA 92: 10531-10534

113. LiW, Srinivasula SM, Chai J, LiP, Wu JW, Zhang Z, Alnemri ES and Shi Y (2002) Structural insights into the pro-apoptotic function of mitochondrial serine protease HtrA2/Omi. Nat. Struct. Biol. 9: 436-441

114. Pallen MJ and Wren BW (1997) The HtrA family of serine proteases. Mol. Microbiol. 26: 209-221

115. Spiess C, Beil A and Ehrmann M (1999) A temperature-dependent switch from chaperone to protease in a widely conserved heat shock protein. Cell 97: 339 347

116. Parrish J, Li L, Klotz K, Ledwich D, Wang X and Xue D (2001) Mitochondrial endonuclease $\mathrm{G}$ is important for apoptosis in C. elegans. Nature 412: 90-94

117. Cote J and Ruiz-Carrillo A (1993) Primers for mitochondrial DNA replication generated by endonuclease G. Science 261: $765-769$

118. Robertson JD, Orrenius S and Zhivotovsky B (2000) Review: nuclear events in apoptosis. J. Struct. Biol. 129: 346-358

119. Enari M, Sakahira H, Yokoyama H, Okawa K, Iwamatsu A and Nagata S (1998) A caspase-activated DNase that degrades DNA during apoptosis, and its inhibitor ICAD. Nature 391: 43-50

120. Liu X, Zou H, Slaughter $C$ and Wang X (1997) DFF, a heterodimeric protein that functions downstream of caspase-3 to trigger DNA fragmentation during apoptosis. Cell 89: 175-184

121. Sakahira H, Enari M and Nagata S (1998) Cleavage of CAD inhibitor in CAD activation and DNA degradation during apoptosis. Nature 391: $96-99$

122. Zhang J, Liu X, Scherer DC, van KaerL, Wang Xand Xu M (1998) Resistance to DNA fragmentation and chromatin condensation in mice lacking the DNA fragmentation factor 45. Proc. Natl. Acad. Sci. USA 95: 12480-12485 
123. Mcllroy D, Tanaka M, Sakahira H, Fukuyama H, Suzuki M, Yamamura K Ohsawa Y, Uchiyama Y and Nagata S (2000) An auxiliary mode of apoptotic DNA fragmentation provided by phagocytes. Genes Dev. 14: 549-558

124. Oberhammer F, Wilson JW, Dive C, Morris ID, Hickman JA, Wakeline AE, Walker PR and Sikorska M (1993) Apoptotic death in epithelial cells: cleavage of DNA to 300 and/or $50 \mathrm{~kb}$ fragments prior to or in the absence of internucleosomal fragmentation. EMBO J. 12: 3679-3684

125. Samejima K, Tone S and Earnshaw WC (2001) CAD/DFF40 nuclease is dispensable for high molecular weight DNA cleavage and stage I chromatin condensation in apoptosis. J. Biol. Chem. 276: 45427-45432

126. Widlak P, Li LY, Wang X and Garrard WT (2001) Action of recombinant human apoptotic endonuclease $G$ on naked DNA and chromatin substrates. Cooperation with exonuclease and DNase I. J. Biol. Chem. 276: 48404-48409

127. Clem RJ (2001) Baculoviruses and apoptosis: the good, the bad, and the ugly. Cell Death Differ. 8: 137-143

128. Thomson BJ (2001) Viruses and apoptosis. Int. J. Exp. Pathol. 82: 65-76

129. Lam E, Kato N and Lawton M (2001) Programmed cell death, mitochondria and the plant hypersensitive response. Nature 411: 848-853

130. Mancini M, Nicholson DW, Roy S, Thornberry NA, Peterson EP, CasciolaRosen LA and Rosen A (1998) The caspase-3 precursor has a cytosolic and mitochondrial distribution: implications for apoptotic signaling. J. Cell. Biol. 140: 1485- 1495

131. Samali A, Zhivotovsky B, Jones DP and Orrenius S (1998) Detection of procaspase-3 in cytosol and mitochondria of various tissues. FEBS Lett. 431: $167-169$

132. Susin SA, Lorenzo HK, Zamzami N, Marzo I, Brenner C, Larochette N, Prevost MC, AlzariPM and Kroemer G (1999) Mitochondrial release of caspase-2 and -9 during the apoptotic process. J. Exp. Med. 189: 381-394

133. Zhivotovsky B, Samali A, Gahm A and Orrenius S (1999) Caspases: their intracellular localization and translocation during apoptosis. Cell Death Differ. 6: $644-651$

134. Qin ZH, Wang Y, Kikly KK, Sapp E, Kegel KB, Aronin N and DiFiglia M (2001) Pro-caspase- 8 is predominantly localized in mitochondria and released into cytoplasm upon apoptotic stimulation. J. Biol. Chem. 276: 8079-8086

135. Chandler JM, Cohen GM and MacFarlane M (1998) Different subcellular distribution of caspase- 3 and caspase-7 following Fas-induced apoptosis in mouse liver. J. Biol. Chem. 273: 10815-10818
136. Costantini P, Bruey JM, Castedo M, MetivierD, Loeffler M, Susin SA, Ravagnan L, Zamzami N, Garrido C and Kroemer G (2002) Pre-processed caspase-9 contained in mitochondria participates in apoptosis. Cell Death Differ. 9:82-88

137. Van Loo G, Demol H, van Gurp M, Hoorelbeke B, Schotte P, Beyaert R, Zhivotovsky B, Gevaert K, Declercq W, Vandekerckhove J and Vandenabeele $P$ (2002) A matrix-assisted laser desorption ionization post-source decay (MALDI-PSD) analysis of proteins released from isolated liver mitochondria treated with recombinant truncated Bid. Cell Death Differ. 9: 301-308

138. Patterson SD, Spahr CS, Daugas E, Susin SA, Irinopoulou T, Koehler C and Kroemer $G$ (2000) Mass spectrometric identification of proteins released from mitochondria undergoing permeability transition. Cell Death Differ. 7: 137-144

139. Hirsch T, Decaudin D, Susin SA, Marchetti P, Larochette N, Resche-Rigon M and Kroemer G (1998) PK11195, a ligand of the mitochondrial benzodiazepine receptor, facilitates the induction of apoptosis and reverses Bcl-2-mediated cytoprotection. Exp. Cell Res. 241: 426-434

140. Jin H, Kendall E, Freeman TC, Roberts RG and Vetrie DL (1999) The human family of Deafness/Dystonia peptide (DDP) related mitochondrial import proteins. Genomics 61: 259-267

141. Adrain C, Creagh EM and Martin SJ (2001) Apoptosis-associated release of $\mathrm{Smac} / \mathrm{DIABLO}$ from mitochondria requires active caspases and is blocked by Bcl-2. EMBO J. 20: 6627-6636

142. Soussi B, Bylund-Fellenius AC, Schersten T and Angstrom J (1990) 1H-n.m.r. evaluation of the ferricytochrome c-cardiolipin interaction. Effect of superoxide radicals. Biochem. J. 265: 227-232

143. Ardail D, Privat JP, Egret-Charlier M, Levrat C, Lerme F and Louisot P (1990) Mitochondrial contact sites. Lipid composition and dynamics. J. Biol. Chem. 265: $18797-18802$

144. Melino G, Bernassola F, Knight RA, Corasaniti MT, Nistico G and Finazzi-Agro A (1997) S-nitrosylcation regulates apoptosis. Nature 388: 432-433

145. Mannick JB, Schonhoff C, Papeta N, Ghafourifar P, Szibor M, Fang K and Gaston B (2001) S-Nitrosylation of mitochondrial caspases. J. Cell. Biol. 154: $1111-1116$

146. Leist M, Single B, Naumann H, Fava E, Simon B, Kuhnle S and Nicotera P (1999) Inhibition of mitochondrial ATP generation by nitric oxide switches apoptosis to necrosis. Exp. Cell Res. 249: 396-403 